\title{
Effects of pulsed nutrient enrichment on enclosed phytoplankton: ecophysiological and successional responses
}

\author{
Marta Estrada*, Elisa Berdalet, Magda Vila, Cèlia Marrasé \\ Institut de Ciències del Mar-CMIMA (CSIC), Passeig Marítim de la Barceloneta 37-49, 08003 Barcelona, Spain
}

\begin{abstract}
A microcosm experiment was carried out during early spring 1994 in order to investigate the effect of Si-sufficient but low N:P ratio or high N:P ratio nutrient inputs, added at different frequencies, on phytoplankton succession patterns. Eight Perspex cylinders were filled with $30 \mathrm{l}$ of coastal water from Masnou (20 km north of Barcelona) and placed in a chamber at $17^{\circ} \mathrm{C}$ under a 12:12 h light:dark photoperiod. Four experimental conditions were randomly assigned to duplicate containers: low N:P ratio (N-deficient) or high N:P ratio (P-deficient) nutrient inputs (including sufficient $\mathrm{Si}$ in all cases), in combination with addition intervals of 2 or $6 \mathrm{~d}$. Integrated chlorophyll a (chl a) concentrations in the P-deficient containers were significantly higher than in the N-deficient ones, presumably due to the faster recycling of $\mathrm{P}$ with respect to $\mathrm{N}$, but differences between addition intervals were non-significant. All microcosms presented an initial bloom dominated by diatoms. In the post-bloom phase, after depletion of the nutrient in short supply, dinoflagellate abundances were higher and diatom abundances lower in the N-deficient than in the P-deficient microcosms. Within nutrient treatments, the qualitative composition of the phytoplankton assemblages was similar across frequencies and replicates. In contrast, characteristics, such as total phytoplankton biovolume or the abundance of dominant taxa, presented significant variability, presumably due to non-linear interactions, even within replicates. This finding suggests the importance of focussing on assemblages rather than on individual taxa when attempting to derive regularities concerning the response of phytoplankton to environmental factors.
\end{abstract}

KEY WORDS: NW Mediterranean · Nitrogen · Phosphorus $\cdot$ Nutrient ratios $\cdot$ Chlorophyll a concentration · Phytoplankton biomass $\cdot$ Phytoplankton succession $\cdot$ Phytoplankton assemblages

\section{INTRODUCTION}

Nutrient availability is a major factor controlling phytoplankton growth. Addition of nutrients from external sources to the euphotic zone results typically in a proliferation of opportunistic, $r$-strategist, fastgrowing forms. More controversial is the extent to which differences in requirements and ability to utilise low concentrations of different nutrients may result in competitive advantages for particular species, when exposed to different nutrient regimes (Tilman 1982). Changes in nutrient supply ratios following eutrophication have been associated with nuisance algal blooms (Smayda 1990) and with events such as the development of mucilage in the Adriatic Sea (Obernosterer \& Herndl 1995) or the proliferation of toxic flagellates (Maestrini \& Granéli 1991). Patterns in the relative availability of major nutrients may be changing even in open sea areas (Karl 1999), highlighting the interest of ascertaining their possible effects on phytoplankton. Microcosm studies have shown that the input ratios of major nutrients like nitrogen $(\mathrm{N})$, phosphorus (P) and silicon ( $\mathrm{Si}$ ) may affect the species composition and succession patterns of enclosed natural communities of phytoplankton (Tilman et al. 1986, Suttle \& Harrison 1988, Estrada et al. 1996, Granéli et al. 1999). Many studies have found a clear effect of Si deficiency in hindering the development of diatom 
populations and, thus, changing drastically the resulting phytoplankton community (Tilman et al. 1986, Estrada et al. 1996, Vila et al. 2001). However, the reported effects of different $\mathrm{N}: \mathrm{P}$ supply ratios on the selection of particular phytoplankton taxa have been variable. Granéli et al. (1999) found that some diatoms were favoured by P-deficient conditions, whereas other diatoms dominated under $\mathrm{N}$ deficiency. On the other hand, Egge (1998) reported that diatoms were not able to dominate under phosphate deficiency, even when silicate and nitrate were in excess. Furthermore, patterns of species dominance in a particular phytoplankton community may depend not only on the absolute amount of available nutrients, but also on the distribution of the nutrient inputs or nutrient patchiness (Harrison \& Turpin 1982, Ghosh et al. 1999, Svensen et al. 2002). Temporal variability in nutrient additions has been considered as a factor promoting increased species diversity by providing a wider resource spectrum and preventing competitive exclusion (Sommer 1985, Grover 1988). These observations lead us to expect that the interaction between nutrient supply ratios and addition frequency may be an important factor in the structuration of natural marine phytoplankton communities.

In the present study, we used a microcosm approach to determine the influence of nutrient pulses with high and low (relatively to Redfield's values) N:P ratios, added at different frequencies, on the succession pattern of marine phytoplankton communities. Our aim was to test the effects of the nutrient treatments on the selection of species assemblages in the nano- and microplankton size ranges ( $>2 \mu \mathrm{m})$ and on 2 basic ecophysiological properties (chlorophyll a [chl a] content and biovolume distribution) of these assemblages. In many situations, such as those concerning harmful algal bloom (HAB) events, it is important to characterise the probability that certain environmental conditions favour a particular species, which may have been targeted due to its harmfulness or other properties. In this context, the results of enclosure experiments are often focussed on a few dominant taxa or on the abundances or biomass of major phytoplankton groups. However, the growth of particular target species may be subjected to many sources of practically unpredictable variability (Huisman \& Weissing 1999). Our approach to overcome this problem was to use multivariate analyses to define assemblages as recurrent groups of taxa (Venrick 1990, Estrada 1991) and to look for regularities in the effects of nutrient ratios at the assemblage rather than at the individual species level.

\section{MATERIALS AND METHODS}

A microcosm experiment was carried out in Barcelona, starting on 19 April 1994 (Table 1). The experimental set-up (Berdalet et al. 1996) consisted of 8 Perspex cylindrical vessels, $200 \mathrm{~cm}$ in height by $15 \mathrm{~cm}$ in diameter, which were filled with 301 of coastal water collected from Masnou (20 km north of Barcelona) and filtered through a $150 \mu \mathrm{m}$ nylon mesh. The microcosms were maintained at $17^{\circ} \mathrm{C}$ in a constant temperature chamber. Light was provided by two $35 \mathrm{~W}, 100 \mathrm{~cm}$ long, fluorescent tubes operating under a 12:12 h light:dark photoperiod. Photosynthetically active irradiance (PAR) in the upper part of the cylinders was $200 \mu \mathrm{E} \mathrm{m} \mathrm{m}^{-2} \mathrm{~s}^{-1}$. Nutrient enrichments (Table 1) with

Table 1. (A) Nutrient concentrations and corresponding N:P ratios of the initial seawater. (B) Calculated nutrient concentration increases reached in the microcosms after each nutrient addition, as performed in the different treatments. The N:P ratios of the nutrient inputs are also given

\begin{tabular}{|c|c|c|c|c|c|c|}
\hline (A) & & & $\begin{array}{c}\text { Nitrate } \\
\left(\mu \mathrm{g} \text {-at } \mathrm{N}^{-1}\right)\end{array}$ & $\begin{array}{l}\text { Phosphate } \\
\left(\mu g \text {-at } \mathrm{P}^{-1}\right)\end{array}$ & $\begin{array}{c}\text { Silicate } \\
\left(\mu \mathrm{g} \text {-at } \mathrm{Si}^{-1}\right)\end{array}$ & $\mathrm{N}: \mathrm{P}$ \\
\hline Initial seawater & & & 1.98 & 0.10 & 0.95 & 19.8 \\
\hline \multirow[t]{2}{*}{ (B) Code } & Treatment & $\begin{array}{c}\text { Addition } \\
\text { frequency }(\mathrm{d})\end{array}$ & $\begin{array}{c}\text { Nitrate } \\
\left(\mu \mathrm{g} \text {-at } \mathrm{N}^{-1}\right)\end{array}$ & $\begin{array}{l}\text { Phosphate } \\
\left(\mu \mathrm{g} \text {-at } \mathrm{P}^{-1}\right)\end{array}$ & $\begin{array}{c}\text { Silicate } \\
\left(\mu \mathrm{g} \text {-at Si } \mathrm{l}^{-1}\right)\end{array}$ & $\mathrm{N}: \mathrm{P}$ \\
\hline & & \multicolumn{5}{|c|}{ Enrichment (per addition) until Day 10} \\
\hline P-def(2) & P-deficient & 2 & 5 & 0.032 & 5 & 156.3 \\
\hline P-def(6) & P-deficient & 6 & 15 & 0.096 & 15 & 156.3 \\
\hline N-def(2) & N-deficient & 2 & 0.5 & 0.32 & 5 & 1.56 \\
\hline \multirow[t]{2}{*}{ N-def(6) } & N-deficient & 6 & 1.5 & 0.96 & 15 & 1.56 \\
\hline & & \multicolumn{5}{|c|}{ Enrichment (per addition) after Day 12} \\
\hline P-def(2) & P-deficient & 2 & 10 & 0.192 & 10 & 52.08 \\
\hline P-def(6) & P-deficient & 6 & 30 & 0.576 & 20 & 52.08 \\
\hline N-def(2) & $\mathrm{N}$-deficient & 2 & 3 & 0.64 & 10 & 4.69 \\
\hline N-def(6) & $\mathrm{N}$-deficient & 6 & 9 & 1.92 & 20 & 4.69 \\
\hline
\end{tabular}


high N:P ratios (P-deficient or P-def) and low N:P ratios ( $\mathrm{N}$-deficient or $\mathrm{N}$-def) were added at intervals of $2 \mathrm{~d}$ (Treatments P-def[2] or N-def[2], respectively) or $6 \mathrm{~d}$ (P-def[6] or N-def[6], respectively) to pairs of containers (hereafter noted as replicates ' $a$ ' and ' $b$ '). $\mathrm{N}$ and $\mathrm{P}$ were provided as sodium nitrate $\left(\mathrm{NaNO}_{3}\right)$ and sodium monophosphate $\left(\mathrm{NaH}_{2} \mathrm{PO}_{4} \cdot \mathrm{H}_{2} \mathrm{O}\right)$. Sodium silicate (Table 1) and a metal supplement consisting of the elements used in the $f / 2$ medium were added to all the microcosms, in the proportion corresponding to the non-deficient nutrient (Guillard 1975). The amount of nutrients added was increased after Day 12 (Table 1), following the decline of the initial chl a peak. The nutrient concentrations in each addition of the $6 \mathrm{~d}$ frequency treatments were 3 times those of the $2 \mathrm{~d}$ treatments.

The nutrient additions were calculated so that the ratio between the amount of $\mathrm{N}$ added in the P-def treatments and the amount of $\mathrm{P}$ added in the $\mathrm{N}$-def ones was 15.6, close to the Redfield value. The choice of $2 \mathrm{~d}$ intervals was based on the results of Sciandra (1991), who found considerable differences in the growth rate response of the red tide dinoflagellate Prorocentrum minimum when subjected to nutrient pulses every 1 or $2 \mathrm{~d}$, in comparison with every $3 \mathrm{~d}$.

Microcosms were sampled at the same time of day, before the nutrient additions. Nitrate, ammonium, phosphate and silicate concentrations in the microcosms were determined daily, using an autoanalyser and following the procedures of Strickland \& Parsons (1972). Chl a was measured fluorimetrically (Yentsch \& Menzel 1963), as described in Estrada et al. (1996); $10 \mathrm{ml}$ of water were filtered through Whatman GF/F filters, which were introduced into $90 \%$ acetone, ground and stored in the dark for $30 \mathrm{~min}$ at room temperature. Fluorescence readings were obtained with a Turner Designs fluorometer.

The taxonomic composition of phytoplankton was examined on 5 occasions. Aliquots of $50 \mathrm{ml}$ of water were fixed with Lugol's solution and stored in Pyrex glass bottles. Cell counts were performed with an inverted microscope (Utermöhl 1958), using $10 \mathrm{ml}$ sedimentation chambers. One transect of the chamber was examined at $600 \times$ to enumerate the most abundant forms; an additional transect and the whole chamber bottom were observed at $125 \times$ to count the larger and less frequent organisms. Cells were classified to the lowest possible taxonomic level, but many of them could not be identified and had to be placed together in categories like 'flagellates' or 'small dinoflagellates'. It must be noted that the inverted microscope method is not adequate for autotrophs in the picoplankton size range $(<2 \mu \mathrm{m})$. Cell biovolumes of the main phytoplankton taxa or groups were obtained following the geometric formulas of Edler (1979), after measuring the dimensions of at least 25 cells per taxon or group with an inverted Nikon Diaphot microscope in combination with a video camera and an image analyser. Heterotrophic bacteria were enumerated by epifluorescence microscopy of DAPI-stained filters (Porter \& Feig 1980). Unless otherwise stated, the phytoplankton data considered below are based on the results of the inverted microscope counts.

The Shannon diversity index, Sh (bits per cell), was calculated for each sample according to the expression (Margalef 1957):

$$
\mathrm{Sh}=\sum_{i=1}^{n} p_{i} \log _{2}\left(p_{i}\right)
$$

where $n$ is the number of taxa and $p_{i}$ is the proportion of taxon $i$ in the sample.

A principal component analysis (Blasco et al. 1980) was performed using the correlation matrix among the logarithm transformed abundances of the 28 most frequent taxa.

\section{RESULTS}

\section{Nutrient concentrations and abundance of heterotrophic bacteria}

The natural seawater used for the experiment (Table 1) contained ca. $2 \mu \mathrm{M}$ of nitrate, $0.95 \mu \mathrm{M}$ of silicate and $0.10 \mu \mathrm{M}$ of phosphate. In the N-def and P-def microcosms, respectively, nitrate and phosphate tended to disappear rapidly from the medium, while they accumulated, respectively, in the P-def and N-def containers (Fig. 1). Ammonium presented an initial decrease, coinciding with the chl a peak, but increased subsequently in all the treatments until becoming more or less stabilised at concentrations around $4 \mu \mathrm{M}$. At the end of the experiment, silicate became undetectable in the $2 \mathrm{P}$-def treatments, although it had been included in the nutrient additions (Fig. 1, Table 1).

The abundance of heterotrophic bacteria increased from the beginning until the end of the experiment (Fig. 2). In the P-def(6) and N-def(6) treatments, nutrient additions on Days 12 and 18 appeared to be followed by slight pulses of growth superimposed on the overall trend. Apart from this observation, no obvious differences could be seen among treatments.

\section{Phytoplankton biomass and composition}

The evolution of the chl a concentration in the different treatments is shown in Fig. 3. An initial chl a peak was observed in all the treatments, with concentrations of 12 to $15 \mathrm{\mu g} \mathrm{l}^{-1}$. Following the initial maxi- 

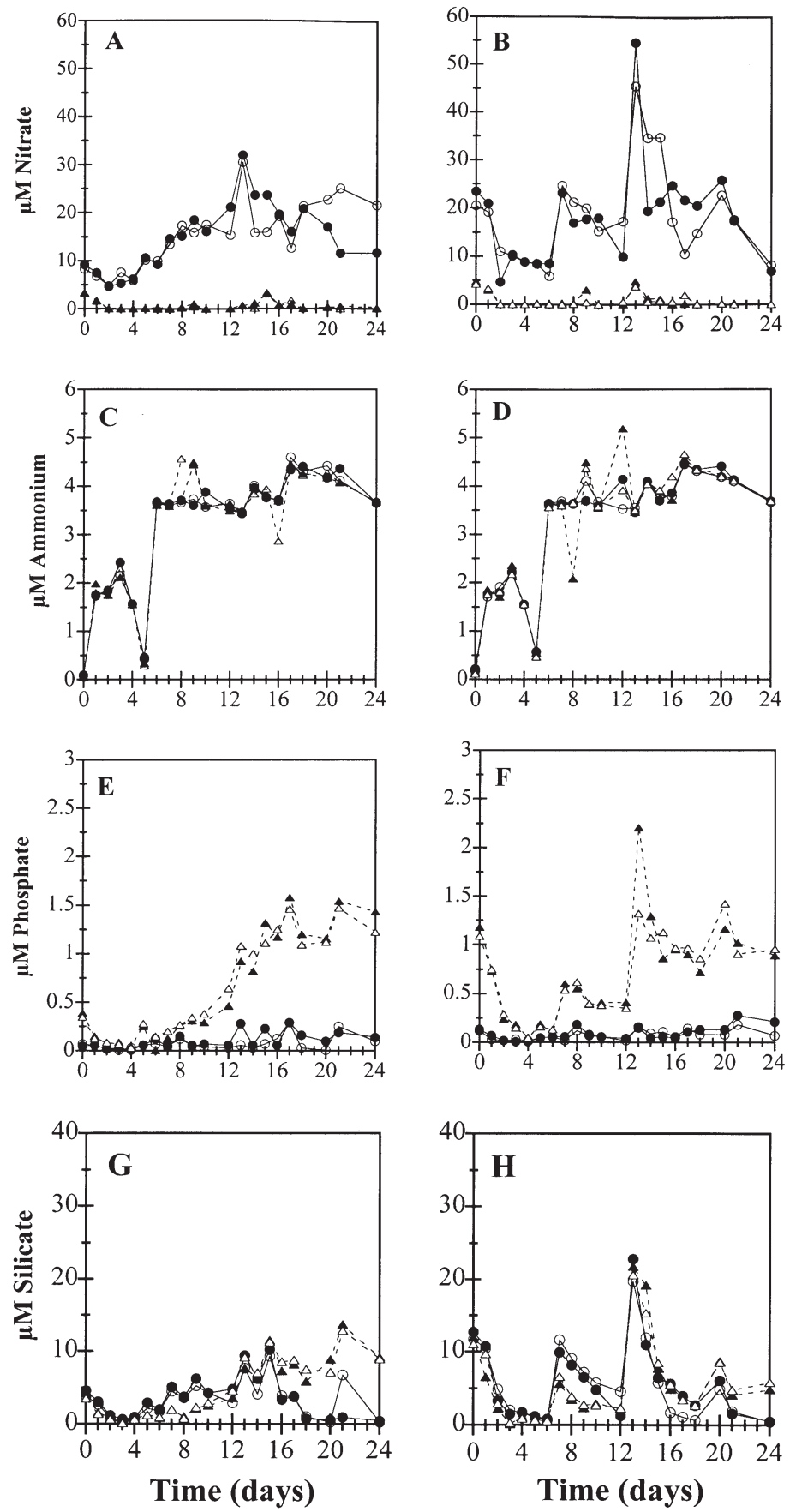

$\longrightarrow$ P-def(2)a-1-N-def(2)a

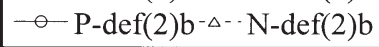

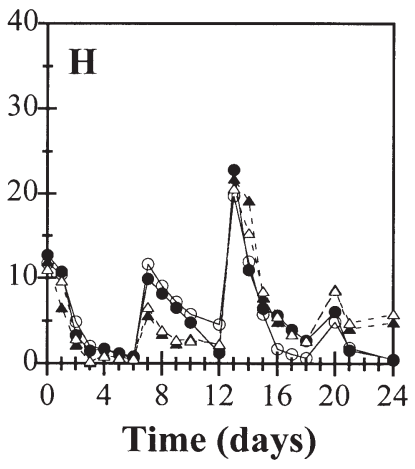

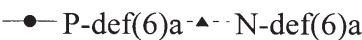
$\rightarrow$ P-def(6)b- $b^{--} N-\operatorname{def}(6) b$

Fig. 1. Temporal changes of the inorganic nutrient concentrations. $(A, B)$ Nitrate, $(C, D)$ ammonium, $(E, F)$ phosphate, $(G, H)$ silicate. P-def and N-def: high N:P ratio and low N:P ratio treatments, respectively, as described in Table 1. Panels A, C, $\mathrm{E}$ and $\mathrm{G}$ correspond to the P-def(2) and N-def(2) treatments, with nutrient additions every $2 \mathrm{~d}$, and $\mathrm{B}, \mathrm{D}, \mathrm{F}$ and $\mathrm{H}$ refer to the P-def(6) and N-def(6) treatments, with additions on Days 0, 6, 12 and 18 . The 2 replicates, ' $a$ ' and ' $b$ ', of every treatment are indicated by open and closed symbols, respectively
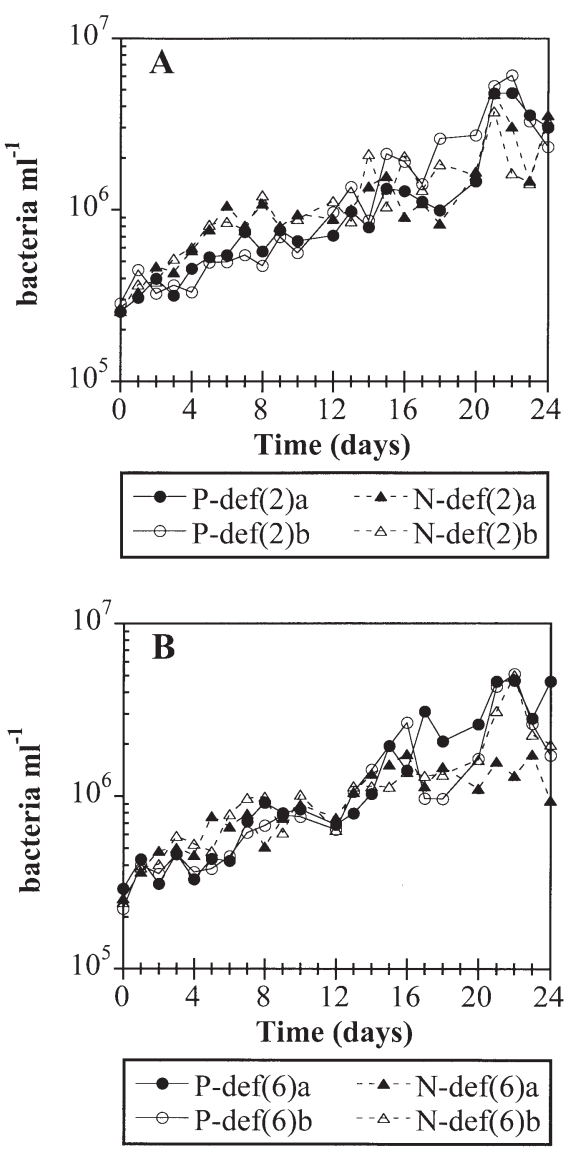

Fig. 2. Temporal changes of the abundance of heterotrophic bacteria in the P-def and N-def treatments receiving nutrient additions every (A) 2 and (B) 6 d. Treatments and symbols explained in Fig. 1

mum, chl a concentration continued to fluctuate, with stronger oscillations in the P-def treatments. In some replicates like P-def(6)a and P-def(6)b, these oscillations were out of phase. Therefore, to avoid masking relationships among variables, the temporal variability of chl $a$ and the main phytoplankton groups has been represented separately for each replicate. Averages have been used for properties less dependent on biomass, such as diversity-related variables and component scores (see Figs. $7 \&$ 8). The time of appearance of the initial chl a maximum was similar for all the treatments of each experiment; however, chl $a$ concentrations tended to be higher in the P-def tubes, which presented significantly higher values of integrated chl a for the whole experiment (Kruskal-Wallis test, $\mathrm{p}<0.05)$. No significant differences were found among frequency treatments. In the last 2 samplings, the $2 \mathrm{P}$-def treatments presented higher biovolumes than the $\mathrm{N}$-def ones (Fig. 4; due to the low temporal resolution, no integrated biovolume values were calculated). 

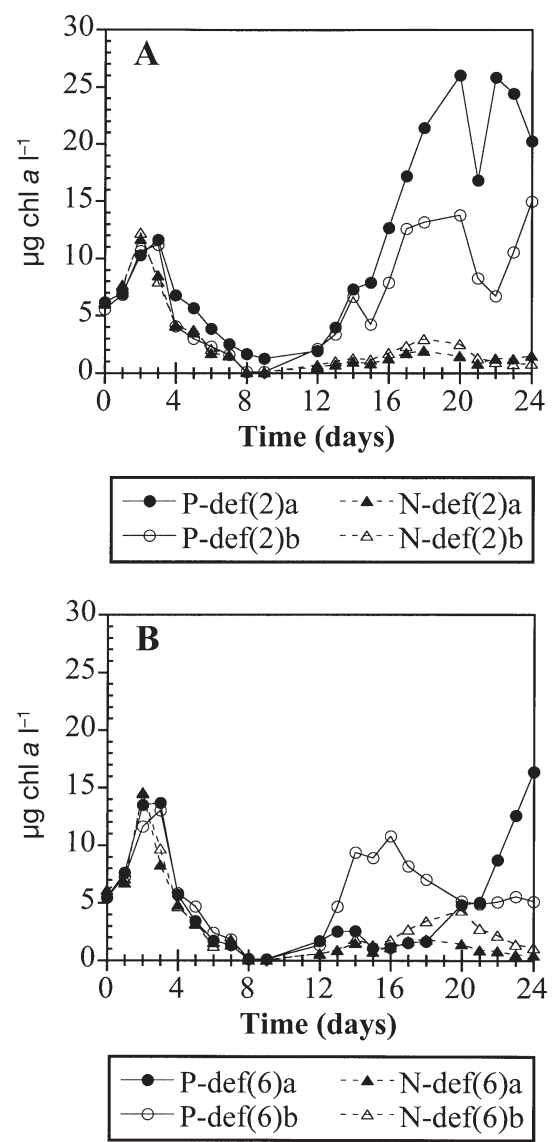

Fig. 3. Temporal changes of the chlorophyll a (chl a) concentration in the P-def and $\mathrm{N}$-def treatments receiving nutrient additions every (A) 2 and (B) 6 d. Treatments and symbols explained in Fig. 1

The initial phytoplankton peaks in the P-def treatments were contributed mainly by diatoms (Fig. 5), with Skeletonema costatum and Leptocylindrus danicus as the dominant taxa (Fig. 6). The importance of diatoms in terms of biovolume decreased in the post-bloom (Fig. 5) sampling (Day 6), but they became dominant again in the later phases of the experiment, with forms like Chaetoceros spp., L. danicus and Pseudo-nitzschia spp. (Fig. 6). Other groups, like the flagellates, were only important in the post-bloom sampling (Fig. 5). In the initial peaks of the N-def treatments, S. costatum and $L$. danicus also contributed almost all of the phytoplankton biovolume (Fig. 6). Flagellates dominated on Day 6, followed by a marked dinoflagellate peak on Day 14 (Fig. 5). Diatoms and flagellates in the N-def microcosms increased again at the end of the experiment, but the diatom abundances were lower than in the P-def treatments. The qualitative composition of the phytoplankton community in the 2 replicates of each treatment was similar, although the oscillations of each replicate were out of phase and sometimes different

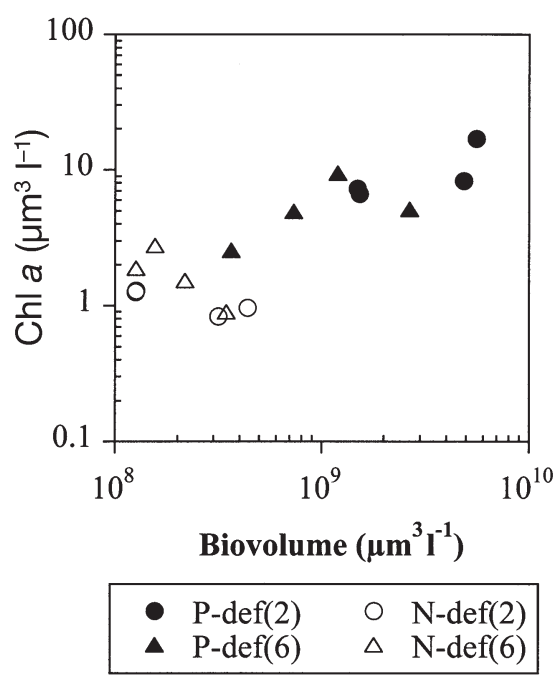

Fig. 4. Relationship between total phytoplankton biovolume and chlorophyll a chl (a) concentration for Days 14 and 20. Treatments explained in Fig. 1. The 2 replicates of each treatment are shown with the same symbol

taxa dominated in each replicate. For example, L. danicus and Chaetoceros spp. dominated at the end of Pdef(2)a and P-def(2)b, respectively (Fig. 6). The effect of the addition interval was small; only in the second half of the experiment did the P-def(2) tubes present higher diatom numbers than the P-def(6) ones (Fig. 5). The average number of identified taxa (including species and other categories) in the containers ranged from 7-10 at the beginning of the experiment to 10-20 in later days (Fig. 7A). The Shannon diversity index increased from values around 0.5 at the beginning of the experiment to 1.5-2.5 at the end (Fig. 7B). No consistent differences in the number of taxa or diversity index could be detected among treatments. The high variability of the Shannon diversity index could be explained because of the phase differences in the fluctuations of the phytoplankton community among replicates.

The variability of the species composition of the phytoplankton assemblages was summarised using principal component analysis. The cumulative variance explained by the first 2 components was $34.2 \%$.

The first principal component (C1) decreased from the beginning to the end of the experiment in the P-def tubes, while it tended to stabilise after the 3rd sampling in the N-def ones (Fig. 8A, Table 2). The positively correlated taxa with $\mathrm{C} 1$ were dinoflagellates (Scrippsiella cf. trochoidea, Gyrodinium spp.) and flagellates (including an unidentified eutreptophyte) which were well represented in the initial inoculum, together with diatoms (Skeletonema costatum) which formed the bulk of the initial phytoplankton peak. Negatively correlated taxa comprised several diatoms (Chaetoceros spp., Licmophora sp., 

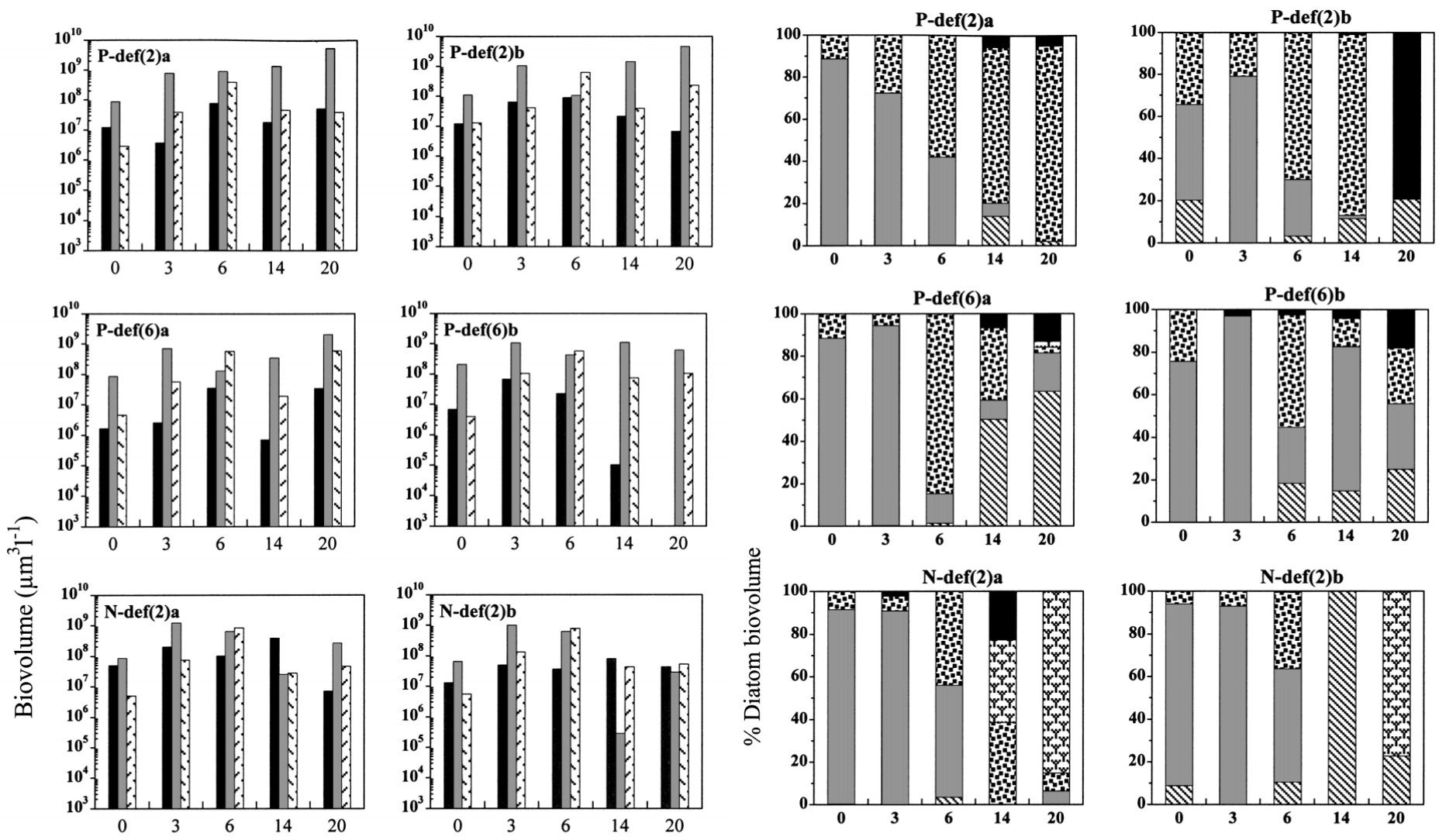

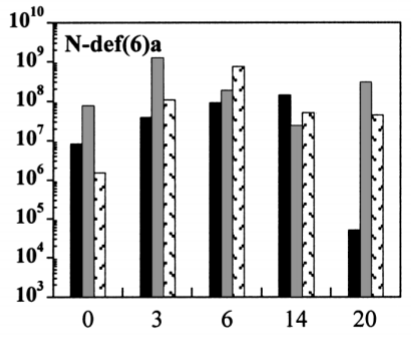

Time (days)
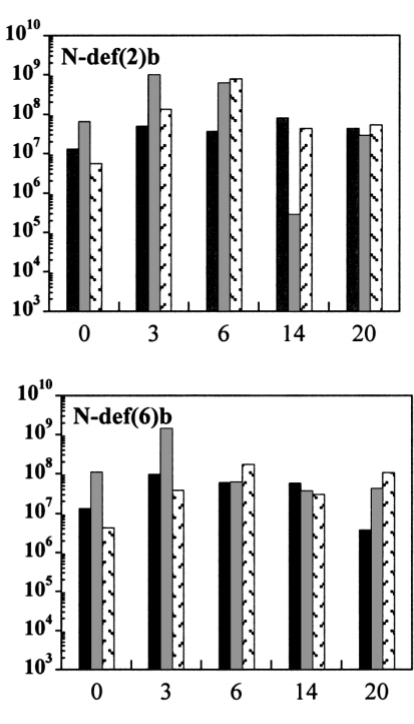

Time (days)

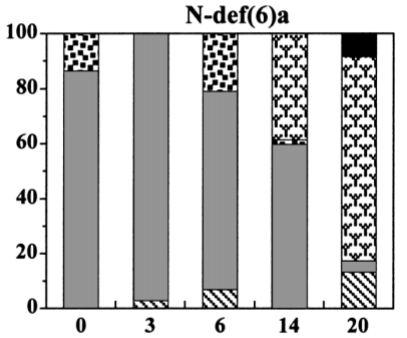

Time (days)

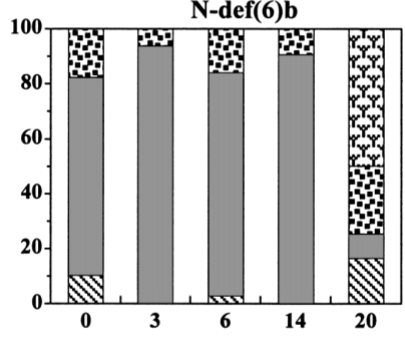

Time (days) dinoflagellates $\square$ diatoms $\quad \nabla$ flagellates

Fig. 5. Contribution of major groups to total phytoplankton biovolume on Days 0 (initial), 3 (initial bloom), 6 (post-bloom), 14 and 20 (secondary bloom). Note the exponential scale of the ordinate. Treatments explained in Fig. 1

Rhizosolenia cf. styliformis, Pseudo-nitzschia spp., Chaetoceros dydimus, etc.) responsible for the late population maxima of the P-def tubes. The second principal component $(\mathrm{C} 2)$ revealed consistent differences in the phytoplankton composition of the N-def and P-def treatments in the late phases of the experiment (Fig. 8B, Table 2). The high positive values of $\mathrm{C} 2$ in the last 2 samplings of the $\mathrm{N}$-def treatments were associated with an increased contribution of several flagellate and dinoflagellate taxa (such as Oblea
Chaetoceros spp.

Cylindroteca closterium Feptocylindrus danicus

Fig. 6. Contribution (\%) of the dominant diatom species to total diatom biovolume on Days 0, 3, 6, 14 and 20. Treatments explained in Fig. 1

rotunda, Gyrodinium spp., Ceratium fusus and some unidentified forms) as well as the diatom Cylindrotheca closterium. The lower values of this component for the P-def treatments reflected the contribution of negatively correlated taxa like the diatoms Leptocylindrus danicus and $S$. costatum, the ciliate Mesodinium sp. and the dinoflagellate $S$. cf. trochoidea. There were no appreciable differences between the scores of the components for different nutrient addition frequencies. 


\section{DISCUSSION}

The objective of the experiment presented here was to test the effect of nutrient additions with high or low $\mathrm{N}: \mathrm{P}$ ratios in shaping physiological properties and succession patterns of phytoplankton communities enclosed in microcosms. As generally found, the response of phytoplankton communities to external forcings ranges from physiological adjustments to taxonomic composition changes. These processes are linked to different levels of organisation (from cells to communities) and occur at different time scales. Therefore, after some general comments on the outcome of the experiment, the following discussion will focus, from shorter (hours to days) to longer (days to weeks) time scales, on: (1) chl a content; (2) biovolume distribution of major groups and dominant taxa; and (3) phytoplankton assemblages.

\section{General comments}

After enclosure, all the tubes developed an initial phytoplankton peak (Fig. 3), which was mainly dominated or contributed to by centric diatoms (Figs. 5 \& 6). This initial peak is a common observation in enclosure
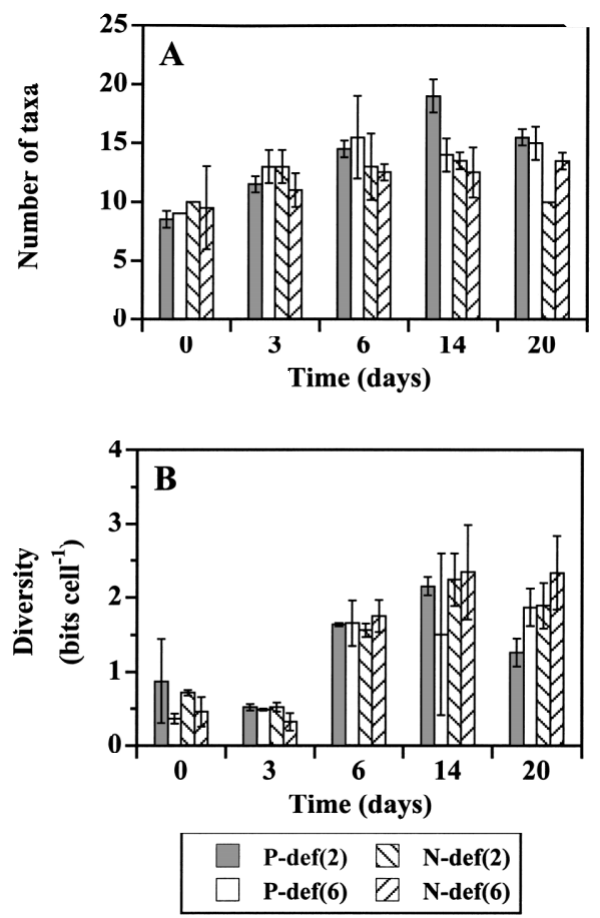

Fig. 7. (A) Number of taxa and (B) Shannon diversity index (bits per cell) in the microcosms on Days 0, 3, 6, 14 and 20. Data shown as mean \pm SE for the pair of replicates corresponding to each treatment. Treatments explained in Fig. 1 experiments and has been attributed to physical changes like reduction of advection losses and increase of available irrradiance, and biological factors like release from grazing pressure due to exclusion of zooplankton (Estrada et al. 1987, Granéli et al. 1999, Svensen et al. 2002).

The crash of the initial bloom (Fig. 3), which occurred approximately at the same time in all the treatments, was presumably related to limitation by the deficient nutrient (phosphate in the P-def and nitrate in the $\mathrm{N}$-def treatments). In the second half of the experiment, continued external forcing (in this case the nutrient additions), possibly interacting with other factors such as predation pressure from ciliates and other microzooplankton, induced oscillations in the phytoplankton biomass, with development of secondary blooms which became out of phase in some of the replicates (especially in the P-def treatments). These oscillations are a typical characteristic of nonlinear systems, and their appearance has been discussed in both experimental and ecosystem modelling approaches (Platt et al. 1981, Dwyer \& Perez 1983, Estrada et al. 1988). In contrast with the strong fluctuations of phytoplankton biomass, bacterial abundance tended to increase throughout the experiment, possibly using organic matter derived from the initial phyto-
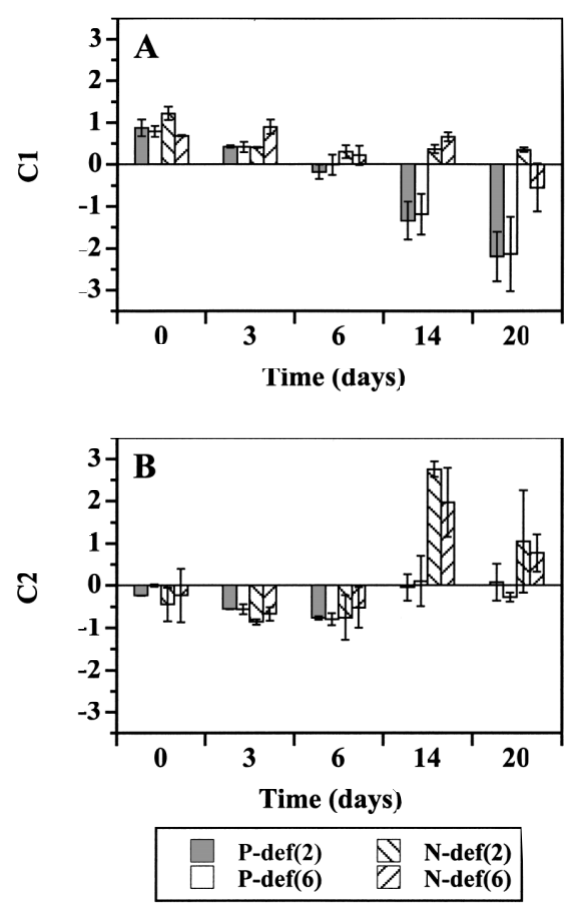

Fig. 8. Scores of the (A) first and (B) second principal components (C1 and C2, respectively) on Days 0, 3, 6, 14 and 20. Data shown as mean \pm SE for the pair of replicates corresponding to each treatment. Treatments explained in Fig. 1 
Table 2. Correlation coefficients (loadings) of the 28 taxa selected for the analysis with the first 2 principal components, $\mathrm{C} 1$ and $\mathrm{C} 2$. Taxa arranged according to correlation coefficient with $\mathrm{C} 1$

\begin{tabular}{|lcc|}
\hline Taxon & $\mathrm{C} 1$ & $\mathrm{C} 2$ \\
\hline Chaetoceros spp. & -0.84 & 0 \\
Pennate diatoms & -0.84 & 0.02 \\
Licmophora sp. & -0.8 & 0.08 \\
Rhizosolenia cf. styliformis & -0.67 & -0.27 \\
Pseudo-nitzschia spp. & -0.63 & -0.24 \\
Chaetoceros didymus Ehrenberg & -0.48 & 0.12 \\
Thalassionema nitzschioides (Grunow) Hustedt & -0.48 & -0.16 \\
Flagellates & -0.47 & -0.28 \\
Haptophytes & -0.39 & -0.31 \\
Dactyliosolen fragilissimus (Bergon) Hasle comb. nov. & -0.37 & -0.12 \\
Leptocylindrus danicus Cleve & -0.34 & -0.59 \\
Unidentified flagellate L & -0.29 & 0.19 \\
Calycomonas sp. & -0.17 & 0.07 \\
Cylindrotheca closterium (Ehr.) Reimann \& Lewin & -0.16 & 0.45 \\
Ceratium fusus (Ehrenb.) Dujardin & -0.11 & 0.27 \\
Unidentified flagellate A & -0.07 & 0.77 \\
Unidentified dinoflagellate A & 0.04 & 0.78 \\
Gymnodinium spp. & 0.05 & -0.08 \\
Protoperidinium spp. & 0.13 & 0.01 \\
Oblea rotunda (Lebour) Balech ex Sournia & 0.13 & 0.78 \\
Skeletonema costatum (Grev.) Cleve & 0.2 & -0.76 \\
Unidenfied dinoflagellates & 0.22 & -0.26 \\
Unidentified ciliates & 0.26 & -0.34 \\
Proboscia (=Rhizosolenia) alata (Brightwell) Sundström & 0.28 & -0.13 \\
Gyrodinium spp. & 0.35 & 0.54 \\
Mesodinium cf. rubrum & 0.37 & -0.5 \\
Scrippsiella cf. trochoidea & 0.39 & -0.46 \\
Eutreptiella sp. & 0.52 & -0.33 \\
\hline
\end{tabular}

plankton bloom. The observation that ammonium concentrations showed similar patterns in all microcosms (Fig. 1), including those with low N:P ratio additions, may be linked to the temporal evolution of bacteria, which was comparable for all the treatments. Presumably, after the initial decrease caused by phytoplankton uptake, ammonium variability was dominated by release due to bacterial decomposer activity. Nutrient addition frequency had only relatively minor effects on the dynamics of the microcosms. The contrast with the findings of Sciandra (1991), who worked with unialgal cultures, may be related to the effect of community interactions, such as excretion by microheterotrophs, in buffering pulses of nutrient input.

\section{Chl a concentration}

$\mathrm{N}$ deficiency was associated with lower chl a concentrations, at least after the initial part of the experiment (Fig. 3). Disregarding the possible effect of differences in the contribution of diverse phytoplankton groups, the relatively low chl a concentrations in the $\mathrm{N}$-def tubes appeared to be associated with the lower phyto- plankton biovolumes in these tubes (Figs. 4 \& 5). The ratios between chl $a$ content and biovolume were more related to the dynamics of the growth phase considered (increasing or decreasing abundances) than to the different treatments.

In our experiments, nutrient addition frequency did not have significant effects on integrated chl a values. Our results can be compared with those of Svensen et al. (2002), who did not find significant differences in chl a concentration when nutrients were added daily or every 3rd day.

\section{Biovolume distribution of major phytoplankton groups}

All nutrient addition treatments appeared to favour proliferations of diatoms (Figs. 5 \& 6). This observation agrees with previous studies (Estrada et al. 1988, Carlsson \& Granéli 1999) and confirms the observations of Estrada et al. (1987), who showed that a diatom bloom after enclosure is a predictable occurrence at times of the year when the inoculum community contains detectable nutrients. After the initial peak, diatoms continued to be an important component of the phytoplankton community, especially in the $\mathrm{N}$-sufficient (P-def) microcosms. This result indicates that, at least for some time after each addition, the absolute amounts of $\mathrm{Si}, \mathrm{N}$ and $\mathrm{P}$ added were sufficient to allow uptake by fast-growing diatoms, even though $\mathrm{N}: \mathrm{P}$ ratios were not balanced. As discussed below, the differences in diatom growth among $\mathrm{N}$ - or P-deficient treatments could be due to a faster recycling of $\mathrm{P}$. The fast-growing diatoms would be the 'velocity-adapted species' described by Crowley (1975) and Sommer (1984). After the phase immediately following the nutrient pulse, other groups could use the strategies of 'storage specialists', which are able to accumulate nutrients and survive between addition intervals, and of 'affinity-adapted species', which have low half-saturation constants that enable them to thrive under nutrient depletion. In this context, the importance of diatoms under unbalanced nutrient addition conditions does not have to be interpreted as a particular adaptation of diatoms to low concentrations of the nutrient considered to be limiting (Egge 1998).

Taking into account that the ratio between the deficient nutrients in the different treatments (nitrate in 
the N-def vs phosphate in the P-def) was close to the Redfield value, a similar biomass (measured here as biovolume) development could have been expected in all the vessels. However, after the initial proliferation, both total phytoplankton biovolume and the diatom contribution to it appeared to be higher under P deficiency (and $\mathrm{N}$ sufficiency) than under $\mathrm{N}$ deficiency (Figs. 4 \& 5). The observation of higher biovolume under P deficiency is likely to be related to the faster turnover of phosphorus with respect to nitrogen (Benítez-Nelson \& Buesseler 1999). The low amount of $\mathrm{P}$ included in the high N:P additions could have allowed the maintenance of a higher biomass than expected from the nominal value of the ratio, as found by Carlsson \& Granéli (1999). P deficiency could also induce higher average cell volume (Berdalet et al. 1994, Latasa \& Berdalet 1994). This was demonstrated in our experiment by measurements taken from some diatom groups (data not shown). However, the differences in phytoplankton biovolume between $\mathrm{N}$-def and P-def treatments (Fig. 4) were mostly associated with differences in cell abundances. There were no significant biovolume differences between addition frequency treatments. A higher proportion of larger forms, capable of nutrient storage, at larger frequency intervals, could have been expected from the findings of Turpin \& Harrison (1979). However, in a microcosm environment, the hypothetical advantage of larger cells is likely to be overridden by other factors, such as mixing conditions, which affect the maintenance of the cells in the water column (Margalef 1978).

Finally, the proliferation of other phytoplankton groups after the decay of the initial bloom was consistently related to varying $\mathrm{N}: \mathrm{P}$ ratios. Thus, in the postbloom phases of the experiment, $\mathrm{N}$ deficiency allowed a stronger growth of dinoflagellates than $\mathrm{P}$ deficiency (Fig. 7), as found by Berdalet et al. (1996) and Estrada et al. (1996) in a microcosm experiment in which nutrients were added in a single initial pulse. It has been speculated that the high P demand of dinoflagellates, due to their relatively high DNA content (Spector 1984, Berman \& Dubinsky 1985), could explain their low contribution in P-deficient microcosms (Berdalet et al. 1996).

\section{Phytoplankton assemblages}

A general finding in enclosure experiments is the strong influence of the initial inoculum in the early phases of the experiment, independent of any nutrient treatments applied (Estrada et al. 1987, Granéli et al. 1999, Reynolds 1999, Svensen et al. 2002). The results of our experiment, which show similar initial phytoplankton responses for all treatments and appearance of consistent differences only after the occurrence of secondary blooms, support the view that unbalanced nutrient ratios per se are not important when the absolute amounts of each nutrient exceed limitation thresholds. As stated by Reynolds (1999), a resource can begin to act as a selective factor only after becoming depleted to levels unable to satisfy demand. It should also be remembered that concentrations do not mirror nutrient availability, as noted by Söderström (1996).

Given the enclosed nature of the microcosms, changes in the number of observed taxa could only be expected by elimination of identifiable forms or by fluctuations of their abundance below or above the detection limits of the counting method. Both the number of taxa and the Shannon diversity index tended to increase throughout the experiment, but they did not show any consistent trends related to nutrient treatments (Fig. 7).

The changes in community composition produced by the P-def and N-def treatments in the last 2 samplings were reflected in the differential variability of the first 2 principal components (Fig. 8). The larger negative values of $\mathrm{C} 1$ for the $\mathrm{P}$-def tubes reflect the stronger development of the diatom community responsible for the secondary blooms, while the larger positive values of $\mathrm{C} 2$ for the $\mathrm{N}$-def containers indicate the contribution of an assemblage formed by dinoflagellates, flagellates and the diatom Cylindrotheca closterium (Fig. 8, Table 2). Several representative taxa of the secondary bloom, characterised by strong negative correlations with C1, like Chaetoceros spp, Pseudo-nitzschia spp. and Thalassionema nitzschioides, comprised the group 'winter-spring diatoms', defined by Vila (2001) as characteristic of the dominant phytoplankton assemblage of the winter-spring bloom in confined coastal waters of the Mediterranean area from which the inoculum for the experiment was taken. The increased contribution of some dinoflagellates and flagellates at the end of the experiment, represented by the positive values of $\mathrm{C} 2$, is in agreement with general trends of phytoplankton succession in the local coastal waters, although there were differences in the dominant species (Vila 2001).

Variability within and among treatments can be explained, in part, by random or chaotic changes in dominance of species with comparable ecological requirements (Beltrami 1995, Huisman \& Weissing 1999). Of course, sampling and counting errors related to both heterogeneities in cell distribution and operator biases should be taken into account when considering determinations of species abundance. However, some observations in the experiments reported here would be difficult to explain by such errors. This situation is evidenced, for example, in the 2 replicates of the P-def(2) treatments (Fig. 6), which were dominated on 
the last sampling day by different diatom taxa, i.e. Leptocylindrus danicus in P-def(2)a and Chaetoceros spp. in P-def(2)b. Similar findings have been reported in natural ecosystems. In coastal confined waters of the NW Mediterranean (Vila 2001), a functional group dominated by bloom-forming dinoflagellates was detected during summer in waters with low water renewal times. However, the dominant species were not always the same. At times, toxic species such as Alexandrium catenella or A. minutum dominated the community whereas, on other occasions, the dominant species were, among others, the non-toxic bloomforming Prorocentrum triestinum, P. micans, Gymnodinium impudicum, Heterocapsa sp. and Scrippsiella spp., which sometimes coexisted with the toxic ones. The underlying message is that the presence of a recurrent assemblage which has been shown to include a harmful alga should be taken as an indication of potential problems with this species.

\section{Concluding remarks}

Our results indicate the importance of considering an adequate level of description when ascertaining effects of factors, such as unbalanced nutrient conditions. In the experiment presented here, marked differences in $\mathrm{chl} a$, biovolume or biomass of the dominant species could be associated with relatively minor differences in the qualitative composition of the whole phytoplankton assemblage, as represented by the principal component scores. Similar results have been obtained by our group in comparable microcosm experiments carried out in other areas (Adriatic Sea), under natural light conditions (unpubl. data). Thus, to derive regularities from the observed phytoplankton variability, it is important to consider, as completely as feasible, the composition of the whole community, rather than a few taxa which may happen to be dominant at a particular moment. We approached this objective using a logarithmic transformation of the abundance data and a multivariate ordination technique (PCA), but other statistical tools could have been applied. In practice, these considerations imply that, even when there is interest in 1 particular species (e.g. because of its toxicity) rather than relying on data for this single species, predictive ability could be gained by ascertaining the assemblage within which it occurs and focussing on the probability of occurrence of this assemblage.

Acknowledgements. Funding for this research was provided by the Institut de Ciències del Mar-CMIMA (CSIC, Spain) and EEC contract no. EV5V-CT92-0215 (MARE project). We thank Dr. Ian Joint for valuable comments on the manuscript. Ms. Roser Ventosa provided technical assistance.

\section{LITERATURE CITED}

Beltrami E (1995) Chance and necessity in harmful algal blooms: a view from models and data. In: Lassus P, Arzul G, Erard E, Gentien P, Marcaillou C (eds) Harmful marine algal blooms. Technique and documentation. Lavoisier, Intercept, Paris, p 551-561

Benítez-Nelson CR, Buesseler KO (1999) Variability of inorganic and organic phosphorus turnover rates in the coastal ocean. Nature 398:502-505

Berdalet E, Latasa M, Estrada M (1994) Effects of nitrogen and phosphorus starvation on nucleic acid and protein content of Heterocapsa sp. J Plankton Res 16:303-316

Berdalet E, Marrasé C, Estrada M, Arin L, Maclean ML (1996) Microbial community responses to nitrogen- and phosphorus-deficient nutrient inputs: microplankton dynamics and biochemical characterization. J Plankton Res 18: 1627-1641

Berman T, Dubinsky Z (1985) The autoecology of Peridinium cinctum fa. westii from Lake Kinneret. Int Ver Theor Angew Limnol Verh 22:2850-2854

Blasco D, Estrada M, Jones JH (1980) Relationship between the phytoplankton distribution and composition and the hydrography in the northwest African upwelling region near Cabo Corbeiro. Deep-Sea Res Part I 27:799-821

Carlsson P, Granéli E (1999) Effects of N:P:Si ratios and zooplankton grazing on phytoplankton communities in the northern Adriatic Sea. II. Phytoplankton species composition. Mar Ecol Prog Ser 18:55-65

Crowley PH (1975) Natural selection and the Michaelis constant. J Theor Biol 50:461-475

Dwyer RL, Perez, KT (1983) An experimental examination of ecosystem linearization. Am Nat 121:305-323

Edler L (1979) Recommendations on methods for marine biological studies in the Baltic Sea. Phytoplankton and chlorophyll. The Baltic Marine Biologists Publication No. 5. p 38

Egge JK (1998) Are diatoms poor competitors at low phosphate concentrations? J Mar Syst 16:191-198

Estrada M (1991) Phytoplankton assemblages across a NW Mediterranean front: changes from winter mixing to spring stratification. In: Ros JD, Prat N (eds) Homage to Ramon Margalef, or why there is such pleasure in studying nature. Oecologia Aquatica, Spec Vol 10. Universitat de Barcelona, p 157-185

Estrada M, Alcaraz M, Marrasé C (1987) Effects of turbulence on the composition of phytoplankton assemblages in marine microcosms. Mar Ecol Prog Ser 38:267-281

Estrada M, Marrasé C, Alcaraz M (1988) Phytoplankton response to intermittent stirring and nutrient addition in marine microcosms. Mar Ecol Prog Ser 48:225-234

Estrada M, Berdalet E, Marrasé C, Arin L, MacLean ML (1996) Effect of different nutrient combinations on phytoplankton development in microcosms. In: Yasumoto $\mathrm{T}$, Oshima Y, Fukuyo Y (eds) Harmful and toxic algal blooms. Intergovernmental Oceanographic Commission, UNESCO, Paris, p 297-300

Ghosh M, Rajendra Prasad KV, Mehta SK, Gaur JP (1999) Response in a natural phytoplankton assemblage to pulsed supply of phosphorus in semicontinuous cultures. Ann Limnol 35:23-29

Granéli E, Carlsson P, Turner JT, Tester PA, Béchemin C, Dawson R, Funari E (1999) Effects of N:P:Si ratios and zooplankton grazing on phytoplankton communities in the northern Adriatic Sea. I. Nutrients, phytoplankton biomass and polysaccharide production. Mar Ecol Prog Ser $18: 37-54$ 
Grover JP (1988) Dynamics of competition in a variable environment: experiments with 2 diatom species. Ecology 69: 408-417

Guillard RRL (1975) Culture of phytoplankton for feeding marine invertebrates. In: Smith W, Chanley MH (eds) Culture on marine invertebrates. Plenum Press, New York, p 26-60

Harrison PJ, Turpin DH (1982) The manipulation of physical, chemical and biological factors to select species from natural phytoplankton communitites. In: Grice GD, Reeve MR (eds) Marine mesocosms. Biological and chemical research in experimental ecosystems. Springer-Verlag, New York, p 275-289

Huisman J, Weissing FJ (1999) Biodiversity of plankton by species oscillation and chaos. Nature 402:407-410

Karl DM (1999) A sea of change: biogeochemical variability in the North Pacific subtropical gyre. Ecosystems 2:181-214

Latasa M, Berdalet E (1994) Effects of nitrogen or phosphorus starvation on pigment composition of cultured Heterocapsa sp. J Plankton Res 16:83-94

Maestrini S, Granéli E (1991) Environmental conditions and ecophysiological mechanisms which led to the 1988 Chrysochromulina polylepis bloom: an hypothesis. Oceanol Acta 14:397-413

Margalef R (1957) La teoría de la información en ecología. Mem R Acad Cienc Artes Barc 32:373-449

Margalef R (1978) Life-forms of phytoplankton as survival alternatives in an unstable environment. Oceanol Acta 1: 493-509

Obernosterer I, Herndl J (1995) Phytoplankton extracellular release and bacterial growth: dependence on the inorganic N:P ratio. Mar Ecol Prog Ser 116:247-257

Platt T, Mann KH, Ulanowicz RE (1981) Mathematical models in biological oceanography. UNESCO, Paris

Porter KG, Feig YS (1980) The use of DAPI for identifying and counting the aquatic microflora. Limnol Oceanogr 25: 943-948

Reynolds CS (1999) Non-determinism to probability, or N:P in the community ecology of phytoplankton. Arch Hydrobiol 146:23-35

Sciandra A (1991) Coupling and uncoupling between nitrate uptake and growth rate in Prorocentrum minimum (Dinophyceae) under different frequencies of pulsed nitrate supply. Mar Ecol Prog Ser 72:261-269

Smayda TJ (1990) Novel and nuisance blooms in the sea: evidence for a global epidemic. In: Granéli E, Sandström B, Edler L, Anderson D (eds) Toxic marine phytoplankton.

Editorial responsibility: William Li,

Dartmouth, Nova Scotia, Canada
Elsevier Science Publishers, New York, p 29-40

Söderström J (1996) The significance of observed nutrient concentrations in the discussion about nitrogen and phosphorus as limiting nutrients for the primary carbon flux in coastal water ecosystems. Sarsia 81:81-96

Sommer U (1984) The paradox of the plankton: fluctuations of phosphorus availability maintain diversity of phytoplankton in flow-through cultures. Limnol Oceanogr 29:633-636

Sommer U (1985) Comparison between steady state and nonsteady state competition: experiments with natural phytoplankton. Limnol Oceanogr 30:335-346

Spector DL (1984) Dinoflagellate nuclei. In: Spector DL (ed) Dinoflagellates. Academic Press, Orlando, p 107-147

Strickland JDH, Parsons TR (1972) A practical handbook of seawater analysis. Bull Fish Res Board Can 167

Suttle CA, Harrison PJ (1988) Ammonium and phosphate uptake rates, N:P supply ratios, and evidence for $\mathrm{N}$ and $\mathrm{P}$ limitation in some oligotrophic lakes. Limnol Oceanogr 33: 186-202

Svensen C, Nejstgaard JC, Egge JK, Wassmann P (2002) Pulsing versus constant supply of nutrients $(\mathrm{N}, \mathrm{P}$ and $\mathrm{Si})$ : effect on phytoplankton, mesozooplankton and vertical flux of biogenic matter. Sci Mar 66:189-203

Tilman D (1982) Resource competition and community structure. Princeton University Press, Princeton, NJ

Tilman D, Kiesling R, Sterner R, Kilham SS, Johnson FA (1986) Green, blue-green and diatom algae: taxonomic differences in competitive ability for phosphorus, silicon and nitrogen. Arch Hydrobiol 106:473-485

Turpin DH, Harrison PJ (1979) Limiting nutrient patchiness and its role in phytoplankton ecology. J Exp Mar Biol Ecol 39:151-166

Utermöhl H (1958) Zur Vervollkommung der quantitativen Phytoplankton-Methodik. Mitt Int Ver Theor Angew Limnol 9:1-38

Venrick EL (1990) Phytoplankton in an oligotrophic ocean: species structure and interannual variability. Ecology 7: $1547-1563$

Vila M (2001) Harmful algal blooms in the Catalan Coast (NW Mediterranean). PhD thesis, Universitat de Barcelona

Vila M, Garcés E, Masó M, Camp J (2001) Is the distribution of the toxic dinoflagellate Alexandrium catenella expanding along the NW Mediterranean coast? Mar Ecol Prog Ser 222:73-83

Yentsch CS, Menzel DW (1963) A method for the determination of phytoplankton chlorophyll and phaeophytin by fluorescence. Deep-Sea Res 101:23-32

Submitted: July 17, 2002; Accepted: January 13, 2003

Proofs received from author(s): March 31, 2003 